International Journal of Instruction e-ISSN: 1308-1470 • www.e-iji.net

Article submission code: 20210126032953

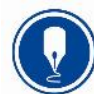

January $2022 \bullet$ Vol.15, No.1

p-ISSN: 1694-609X

pp. 421-436

Received: 26/01/2021

Revision: 04/07/2021
Accepted: 27/07/2021

OnlineFirst: 29/10/2021

\title{
Motivation and Retention of Teaching Foreign Language in South Korea: Perspectives of University Instructors
}

\section{Luis Miguel Dos Santos}

Asst. Prof., Woosong Language Institute, Woosong University, South Korea, luismigueldossantos@yahoo.com

Based on the guidelines of the Social Cognitive Career Theory, the purpose of this study is to understand the motivations and reasons why foreign language university instructors decide to stay in Korea for their life-long career development. This research was guided by one research question, why would foreign university instructors decide to stay in Korea for more than 15 successive years at the same university? With the Interpretative Phenomenological Analysis, ten participants were invited. The results indicated that personal considerations and financial considerations are the most important factors for the career development of these groups of foreign teachers in Korea. This study has contributed to practices devoted to teachers' professional development and career development of foreign teachers. First, the shortage of teachers and educational staff is significant in all locations, regardless of population. Second, the East Asian region is one of the popular destinations for many international students, teachers, and professionals to develop their career goals and personal achievements.

Keywords: foreign teachers, international teaching, interpretative phenomenological analysis, psychology of education, social cognitive career theory, teachers' professional development

\section{INTRODUCTION}

International teaching and schooling programs have been created for foreign professionals and diplomats' children in many non-westernized countries and regions. International schools tend to offer curricula and instruction that are based on the students' home country's educational system - for example, on the British educational system (i.e., IGCSE and the A-Level). International schools also tend to recruit teachers and staff from the students' home country. Although many studies have focused on the students' achievements and the outcomes of the student populations, many teachers in foreign countries face the same challenges and problems that the students do. However, Cushner (2007) (Cushner, 2007) maintained that unlike youths, who can adapt to foreign environments, social backgrounds, and cultural differences, teachers who are teaching in foreign countries always face challenges with regard to the family, community, and institutions. The experiences and expectations from the host country usually have no

Citation: Dos Santos, L. M. (2022). Motivation and retention of teaching foreign language in South Korea: perspectives of university instructors. International Journal of Instruction, 15(1), 421-436. https://doi.org/10.29333/iji.2022.15124a 
connection with what the teachers have learnt. Some teachers may overcome those difficulties, but most do not. As a result, many foreign teachers leave their teaching position in foreign countries within a few years of their contract (Cushner, 2007).

Before teachers officially resign from their position (i.e., notify the human resources department of their resignation), they usually do three things: reconsider the decision, look for other opportunities, and notify the department of their intention (Mowday et al., 1981). However, research has indicated that if individuals cannot find appropriate new opportunities, they are more likely to stay. A previous study (Kartika \& Purba, 2018) investigated the relationship between job satisfaction and turnover thinking among international school teachers in the Asian Pacific region and found that their job satisfaction could be influenced by the school system's organizational leadership and management. Therefore, if employees experience a positive management style, their turnover intention will be reduced. Another recent study (Dos Santos, 2019d) about international school teachers' turnover indicated that location and personal development can influence the teachers' turnover decisions. That study investigated a group of international school teachers who were currently teaching or used to teach in Fiji, an archipelagic and remote country in the Pacific Ocean. Using the lens of the Social Cognitive Career Theory, the results indicated that schools' managerial styles and the location of the international school(s) or countries could highly influence the turnover decisions of international school teachers. However, many respondents also indicated that respectfulness from both the parents and students influenced their self-efficacy and satisfaction (Jones, 2017; Lam \& Yan, 2011), as factors motivating them to stay.

Another previous study (Davis \& Wilson, 2000) indicated that the factors of school leadership and principals' behaviours highly influenced the career development, career decision, satisfaction, and stress of teachers. In fact, many regions and countries are thirsty for qualified and experienced teachers in all subject matters. If teachers do not like or satisfy with their current school and school administrative style, they can easily find other teaching opportunities due to their experiences. According to Weiner (2012), teachers in different school environments, school backgrounds, and subject matters may have different career decisions (Weiner, 2012). For example, teachers in urban teaching and learning environments are more likely to leave their position (i.e. either turnover and leave the teaching profession). The likelihood is much higher than teachers in suburban and rural communities.

In some cases, the teacher-student-ratio takes the important roles in teachers' career decision (Sutcher et al., 2019). In some subject matters, such as foreign language teaching and learning, the ratio between teachers and students is one of the key terms for successful teaching. A recent study (Aeschlimann et al., 2019) indicated that teachers might leave their position due to the unbalanced ratio and other administrative decisions if they cannot balance the responsibilities. The unbalanced teacher-student ratio may influence teachers' career decision. Another recent study (Dos Santos, 2021b) indicated that stress and self-efficacy might influence pre-service teachers' career decision due to the stressful nature of the teaching position, administrative style, and uncertainty of promotion (Wahyudiati et al., 2020). Teaching is one of the demanding positions 
without reasonable salary payments (Aghaei et al., 2020). Many pre-service and juniorlevel teachers may leave the teaching profession completely after their student-teaching internship or the first few years of their teaching services (Amtu et al., 2020).

Earlier studies (Allen et al., 2018; Grissom et al., 2016; Odland \& Ruzicka, 2009) also have argued that frequent departure of teachers and school staff can increase students' confusion and reduce their overall performance and educational experience. For example, a previous study (Atteberry et al., 2017) investigated the case in an urban region, comparing the performance and differences in terms of students' achievements under teachers that were new to the school with those under teachers that had remained in their position and job status for some time. The result indicated that negative outcomes from having high teacher turnover accounted for about $33 \%$ of the magnitude of the influence of a new-to-school teacher (Atteberry et al., 2017).

\section{Purpose of the Study}

As is clear in the background literature for this study, many foreign teachers decide to leave the host countries within the first few years of their teaching services. From the perspective of school management, the frequent departure of teachers and staff always increases the burdens of human resources procedures and costs (i.e., recruitment, training, compensation, etc.) (Watlington et al., 2010). From the perspective of students, summative assessments in their portfolio and developmental reports may not be successfully continued when their teachers leave their positions. Although reasonable turnover and retirement may increase the motivations and teaching and learning strategies for all parties, human resources departments, school leaders, department heads, government agencies, policymakers, and researchers should all understand the motivations and reasons for the career decisions of foreign teachers in Korea.

Based on the guidelines of the Social Cognitive Career Theory, the purpose of this study is to understand the motivations and reasons why foreign language university instructors decide to stay in Korea for their life-long career development. This research was guided by one research question, which was,

Why would foreign university instructors decide to stay in Korea for more than 15 successive years at the same university?

\section{Theoretical Framework: The Social Cognitive Career Theory}

The Social Cognitive Career Theory was created and developed as a direction of establishing ideas, notions, and perspectives linkages for the career decision and motivation of individuals. Originally, in 1994, Lent, Brown, and Hackett (Lent et al., 1994) advocated that self-efficacy beliefs, outcome expectations, and career and educational goals were three of the key factors of this theory.

However, due to the social development of the global communities and the development of the literature review, the additional factor(s) may be added to the Social Cognitive Career Theory. Currently, the researcher argued that financial consideration might be added to the Social Cognitive Career Theory (Dos Santos, 2021a) as one of the most important factors which may influence the career decision. As a result, the researcher 
employed one additional factor (i.e. financial consideration) to explore and investigate the current research question. To illustrate the Social Cognitive Career Theory for this study, please refer to Figure 1.

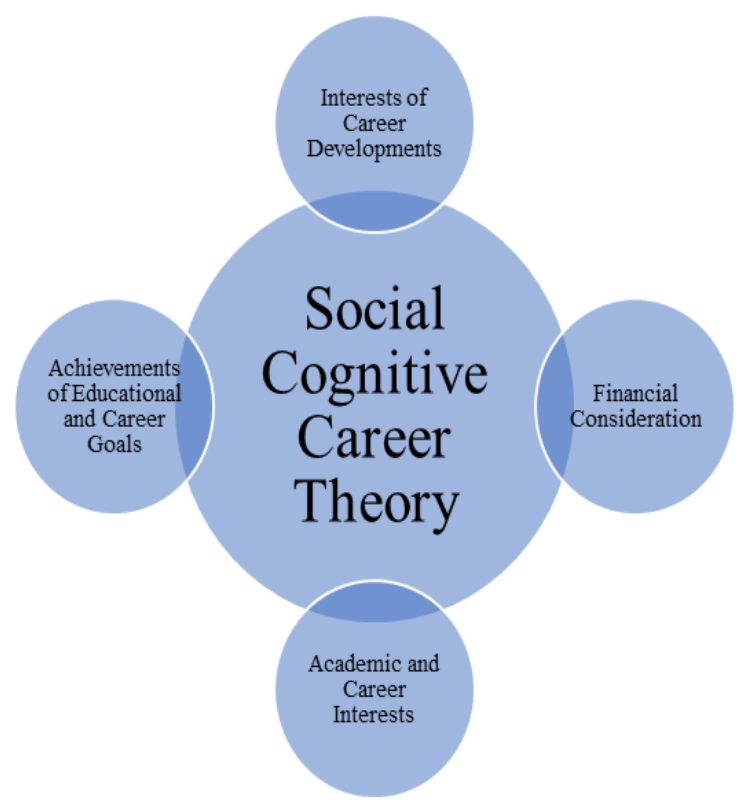

Figure 1

Social cognitive career theory

\section{METHOD}

A qualitative research design (Creswell, 2012; Dos Santos, 2019a) was employed in this study for the understanding of why foreign university instructors decide to stay in Korea for long-term career and life development. This design allows the researcher to gain the understanding, lived stories, perspectives, conceptions, and sharing about this special social phenomenon (Clandnin \& Connelly, 2000) in the East Asian region.

There are three reasons why the qualitative research methodology with the application of the Interpretative Phenomenological Analysis is selected. First, the qualitative research method allowed the researcher to understand and capture the individuals' inner world, social world, and sense-making process. In fact, this study sought to understand the career perspectives, understanding, motivations, and reasons based on the lived stories of the participants. Without the in-depth interviews and sharing of their lived stories, the data could not present these groups' holistic stories.

Second, the Interpretative Phenomenological Analysis focuses on the lived stories and perspectives based on the in-depth sharing from the participants. Unlike the phenomenological analyses with a larger group of individuals, based on the guideline from the Interpretative Phenomenological Analysis, up to ten participants can be 
selected in order to make sure the in-depth orientation of the study. In other words, studies with the Interpretative Phenomenological Analysis could only recruit up to ten participants per study. In this study, ten participants were selected based on the recommendation of the handbook. Last but not least, the small population with multiple interview sessions allowed the researchers to gain in-depth understanding and sharing from the participants. Unlike quantitative data from wider groups of people, the in-depth and intensive data increased the density and in-depth understanding of a particular set of research questions and topic(s). Therefore, the current research design may meet the needs of the current study and the research rationale.

\section{Research Design: The Interpretative Phenomenological Analysis}

application of the Interpretative Phenomenological Analysis (Dos Santos, 2019d, 2020b; Larkin \& Thompson, 2011; Smith et al., 2009; Tang \& Dos Santos, 2017) was employed. As this study focused on why foreign university instructors would decide to stay in Korea for more than 15 successive years at the same university, the researcher was expected to collect in-depth and rich lived stories, personal background, and sharing from the participants. The Interpretative Phenomenological Analysis (Dos Santos, 2019d, 2020b; Larkin \& Thompson, 2011; Smith et al., 2009; Tang \& Dos Santos, 2017) allowed the researcher to seek the in-depth understanding of a lived and life situation and experience of individuals and groups. More importantly, the research studies with the Interpretative Phenomenological Analysis (Dos Santos, 2019d, 2020b; Larkin \& Thompson, 2011; Smith et al., 2009; Tang \& Dos Santos, 2017) background always gain the ideas about how the individuals and groups make sense of their social experience, social world, and inner understanding. Therefore, the application of the Interpretative Phenomenological Analysis (Dos Santos, 2019d, 2020b; Larkin \& Thompson, 2011; Smith et al., 2009; Tang \& Dos Santos, 2017) meets the expectation of this study.

\section{Participants}

The purposive sampling strategy (Merriam, 2009) was used to find individuals who would, the research plans, have the most information on the research question, and for whom the research question may be useful. Based on the research question, the selection factors were that they should live in Korea for more than 15 successive years at the same university (i.e. workplace) as foreigners.

For this study, ten participants were asked to participate. Based on the guideline of the Interpretative Phenomenological Analysis handbook, Interpretative Phenomenological Analysis studies should not recruit more than ten participants for each study. Therefore, the recruit of ten was appropriate (Dos Santos, 2019d, 2020b; Larkin \& Thompson, 2011; Smith et al., 2009; Tang \& Dos Santos, 2017). They all work in the field of English language teaching all across the Korean region. As the research study planned to collect in-depth and rich data from the participant, the researcher needed to control the numbers of the participants. According to the recommendation of the handbook of Interpretative Phenomenological Analysis (Dos Santos, 2019d, 2020b; Larkin \& Thompson, 2011; Smith et al., 2009; Tang \& Dos Santos, 2017), studies should limit 
their numbers of participants (i.e. up to ten individuals). Therefore, the researcher only recruited ten individuals for this study.

\section{Data Collection: The Interview}

First, in order to collect in-depth data from the participants, based on the recommendation from Seidman (Seidman, 2013), the researcher decided to conduct three interview sessions. Both open-ended interview questions and semi-structured interview questions were employed.

As for the first interview session, the researcher sought to understand the reasons why the individuals decided to come to Korea for career development and personal development?

As for the second interview session, the researcher sought to understand the reasons why the individuals decide to stay in Korea for career development and personal development? (i.e. as most of the foreigners left Korea after a few years of their contract).

As for the third interview session, the researcher sought to understand the reasons why the individuals decide to stay in the same university (i.e. workplace) for career development and personal development?

All these interview sessions were conducted in a private room at the local community centers or libraries. During the interview sessions, the sharing and conversations were digitally recorded for further data analysis. Each interview session lasted from 67-91 minutes.

\section{Data Analysis}

The interview sharing and data were transcribed from voiced messages to written transcripts based on the directions of the Interpretative Phenomenological Analysis (Dos Santos, 2019d, 2020b; Larkin \& Thompson, 2011; Smith et al., 2009; Tang \& Dos Santos, 2017). All transcripts and data were read multiple times in order to categorize the themes and groups for the holistic picture of the situation. First, the researcher employed the open-coding technique for the first-level themes and subthemes. The researcher was able to categorize the raw materials into ten themes and 12 subthemes. However, the researcher noted that the themes and subthemes should be further narrowed. Therefore, the researcher merged the first-level themes and subthemes to the second-level themes and subthemes with the directions of the axial-coding technique. As a result, two themes and three subthemes were grouped (Dos Santos, 2019c, 2019b).

\section{Validity}

In order to increase the validity of this study, the researcher employed both tools of member checking interview and material confirmation. All participants had the chance to read their related materials for confirmation (Merriam, 2009). As a result, all participants agreed with their own materials for this study. 


\section{Human Subject Protection}

The privacy of the participants' information is the most important element for this study. Therefore, the researcher tried his best to conduct all ways for protection. All signed agreements/consent forms, personal contacts, email addresses, voice messages, written transcripts, computer, and related materials were locked in a password-protected cabinet. Only the researcher has the rights to read the materials. After the researcher completed the study, the researcher deleted and destroyed all the related materials for personal privacy and protection. As the foreign university instructors' population in Korea is not large, the researcher needed to mask the personal identity of each participant. Therefore, based on the guideline from the agreement/consent form, the participant would be provided with a pseudonym. No sensitive information could be disclosed in order to protect the identity of each participant. It is worth noting without human subject protection, participants could not want to share in-depth and sensitive information of their lived stories.

\section{FINDINGS AND DISCUSSIONS}

Although all participants answered the same interview questions, their individual lived stories and motivations were not identical. However, because most shared detailed, similar situations and experiences in Korea from their recent time there as teachers, the researcher was able to categorize points and themes under certain common threads. To illustrate, the researcher categorized the responses into themes and subthemes, as shown in Table 1.

Table 1

Themes and subthemes

\begin{tabular}{l}
\hline Themes and Subthemes \\
\hline Personal Considerations \\
My Marriage Makes Me Stay \\
\hline I am a Loser in My Home Country \\
\hline Financial Considerations \\
\hline A Higher Salary: I Cannot Make the Same Money Back Home, as I Am Not Competitive \\
\hline
\end{tabular}

\section{Personal Consideration}

The researcher categorized the first common theme as personal considerations, as determined from the sharing of personal experiences and lived stories by ten foreign university instructors in Korea. Unlike most foreign teachers, who may leave to go to another country for further development, these ten participants stayed in Korea for more than 15 successive years at the same school(s). According to a previous study (Hardman, 2001), the majority of international school teachers or teachers who are teaching at international locations, stay in their position for fewer than five years for various reasons, such as cultural differences and their own career development. However, when viewed through the lens of the Social Cognitive Career Theory (Dos Santos, 2019d, 2020a; Lent et al., 1994; Lent \& Brown, 1996), this study's group of ten participants stayed in Korea in response to their own personal considerations. A significant sharing was captured, 
...based on my degree and experiences, I can go to China and Japan for further development...but I think I will stay in Korea...I don't want to change... as I am not young...I don't want to have challenges and moving anymore...it is really personal...my own selection, as I am not going to move to elsewhere in the future...

As participants described in their sharing, although many of them had their own academic achievement and rich working experience, they made a personal decision to give up challenging opportunities for personal reasons, such as age or family issues. Using the framework of the Social Cognitive Career Theory (Dos Santos, 2019d, 2020a; Lent et al., 1994; Lent \& Brown, 1996), the results confirmed that individuals may be driven by their own personal considerations, even if they are comfortable with other elements, such as academic achievement.

\section{My Marriage Makes Me Stay}

Under the theme of personal considerations, the researcher categorized two subthemes, one of which was the subtheme of marriage. According to a recent study (Kim \& Kilkey, 2018), the numbers of international marriage have been increased in Korea due to the development of globalization and freedom of movements. In this case, some of the participants married to Korean spouse, which may influence their decision-making process. All ten of the participants who had remained teaching at their school for 15 or more years were married to a Korean spouse before and during their teaching voyage in Korea. Nine indicated that they wanted to return to their home country after the first few years of their teaching voyage in Korea, but their Korean spouse refused to return (i.e., the spouse insisted on staying in Korea, for long-term development). All indicated that even if they begged for nearly a decade, they had to remain in Korea unwillingly because of their family and marriage commitment. An interesting lived story was captured,

I really want to go back to my home country for both career development and family engagement...my wife has family here...but I have family in the United Kingdom as well...I asked several times and I even applied [for] jobs there...but my wife strongly refused my request...

The above story indicated the issue of conflicts within the family. Based on the Social Cognitive Career Theory (Dos Santos, 2019d, 2020a; Lent et al., 1994; Lent \& Brown, 1996), the participant was mainly concerned about his personal considerations in regard to his marriage. Even if favorable financial considerations were proffered, such as a successful job offer from a position in the United Kingdom, the family still needed to stay in Korea. Another participant shared a similar situation, saying,

...my wife strongly refused the plans [for]Australia...because she told me that she cannot speak English ...but we are talking in English at home with our children...I have to respect her decision...but this is not my own will...I don't want to stay in Korea at all...

All ten participants indicated that they would have liked to go back to their home countries, but their spouse refused. When the researcher further asked about their sense 
of belonging and their general feelings about Korea (i.e., positive, neutral, and negative), all expressed a sense of withdrawal and responded with negative answers and lived stories. A significant lived story was captured,

...Even if I [have] lived in Korea for more than 18 years, I don't think I belong to Korea at all...Korea is an unwelcoming region for non-Korean individuals...even if I can speak Korean fluently, my skin colour always limits my opportunities...people on the street gaze at me all the time...

Indeed, some previous studies (Dos santos, 2020; Lee et al., 2017) have indicated that racism and neo-racism significantly influence the experiences of foreigners in Korea. Skin color(s) and religious practice(s), for example, are used by Korean people to compare and judge individuals based on their personal characteristics and behaviors. Viewed through the lens of the Social Cognitive Career Theory (Dos Santos, 2019d, 2020a; Lent et al., 1994; Lent \& Brown, 1996), no elements other than personal considerations had driven their decision to stay in Korea.

\section{I am a Loser in My Home Country}

The second subtheme of the main theme of personal considerations was problems about their own qualifications and skills (i.e., from their perspectives as foreigners in Korea or as citizens in their home country). First, all participants indicated that they had originally decided to come to Korea because they could not find a stable and satisfying career pathway in their home country. Without any choices at home, they had to leave for a job teaching abroad at an international school. According to a previous study (Todd \& Darasawang, 2020), although many instructors teach at overseas institutions, a large number are unqualified (i.e., lack teaching licenses or related training). In the current study's case, none of the participants had earned their initial teacher's license in their home country, such as the initial license and Qualified Teacher Status (i.e. QTS in England). The researcher captured a sharing,

... who doesn't want to stay in their birthplace and home country?...but I am a loser in my home country...I had bad communication skills...I don't understand how to interact with others...I don't know how to handle office politics...I did several jobs before I left Australia...the only advantage I had was [being] a native English speaker...so I applied [for] a job and received an offer in five days...

According to Tsui (Tsui, 2020), many East Asian countries and regions are thirsty for English language teachers. However, when there are more vacancies than applicants, unqualified candidates will be taken on in order to fill the need for teachers. The results from this study revealed that when unqualified teachers sought career pathways in Korea, they were less likely to leave their positions later (i.e., because they could not find a similar position afterwards). Looking through the lens of Social Cognitive Career Theory (Dos Santos, 2019d, 2020a; Lent et al., 1994; Lent \& Brown, 1996), the researcher stated that the participants' decisions to stay in Korea were due to their personal decisions and the disadvantages of their academic backgrounds. 
Moreover, when the researcher further asked why the respondents would not enroll in the initial teacher's training program for potential career development, many indicated that they were not effective learners. Almost all indicated that if they had been able to study, they would not have needed to leave their home country in the first place. One significant sharing was captured,

...I did a bad job for my SAT exam...I used three years to complete my associate degree and three more years for my bachelor's degree... with only 2.3 GPA...I couldn't find any jobs because of my grades and unknown university networks...my professors asked me to continue my pathway with a master's degree...but I failed my GRE again... until I applied [for] a random job in Korea...this was my only choice...or I had to sleep on the street...

The above lived story was a single case, but many shared similar stories about their education and job-seeking. Through the lens of the Social Cognitive Career Theory (Dos Santos, 2019d, 2020a; Lent et al., 1994; Lent \& Brown, 1996), personal considerations thus ranked as the important factor for coming to Korea. In short, even if the participants had opportunities or desires to move to other countries, they were not as well-equipped as the new generations are with qualifications and licenses. As a result, they had to stay in Korea (i.e., the same school and position) as foreign language teachers.

\section{Financial Considerations}

In addition to the first theme, that of personal considerations, many expressed financial concerns as a factor in their decisions to remain in Korea (Dos Santos, 2019d, 2020a; Lent et al., 1994; Lent \& Brown, 1996). With the reflection of the above data and stories, many participants were unprepared and were not well-equipped. For example, many indicated that they had worked in the teaching profession for nearly two decades, but their qualifications and background had not been upgraded. Because the education profession relies heavily on teachers' qualifications and licenses, these groups of participants could not obtain the same position (i.e., administrative positions) in their home country. More importantly, as a result of their inability to advance, the inadequate resources of their junior-level positions at home would have kept them from being able to afford their family expenses. One said,

I tried to apply [for] different positions in the United States. But I am only qualified for the entry level teachers' position...[and with] the salary of junior-level teachers [I] could not afford my family expenses...I have two children and my wife is a housewife who cannot speak English...I will be the only one [to earn] money...the financial stress is the biggest concern...

A Higher Salary: I Cannot Make the Same Money Back Home, As I am not Competitive

Under the subtheme about salary and career competition, all ten participants indicated that they were satisfied with their salary in Korea (due to the country's regular annual increases for the same position). First, many indicated that because they did not have 
any postgraduate degrees, it was hard to seek a similar salary range outside of Korea. One said,

...I don't have a master's or doctoral degree...I think most of the experienced teachers in Korea don't... we have no choice... it is impossible to find a job with the same salary level...without a master's degree or so...I have applied for other positions elsewhere...for positions without the requirement of postgraduate degrees...the salary was not nice...

A previous study (Han et al., 2018) indicated that teachers face low-level salaries, high levels of stress, and excessive responsibilities, regardless of their social environment. The results of the current study reflect concerns about the relationship between salary and responsibilities. The participants indicated that their salary in Korea was high enough for their family expenses and leisure activities due to the annual increases. The teachers would not give up that salary because they were not competitive enough to obtain other positions with the same salary. On the basis of the Social Cognitive Career Theory (Dos Santos, 2019d, 2020a; Lent et al., 1994; Lent \& Brown, 1996), the participants' financial considerations confirmed that finances played a role in the participants' career decisions (i.e., to stay in Korea).

Due to the convenient access of postgraduate education in Korea in recent decades, such as blended and distance-learning programs, a large number of newer-generation candidates have gained their doctoral degree. As a result, this study's participants were at a disadvantage because of their limited qualifications. Although some may argue that working experience is worthy of consideration, in many recent vacancies, the preferred candidates had a doctoral degree. Citing that reason, one participant shared a story,

There are many opening for senior-level teachers and administrators...but I don't have a doctoral degree...for both Korea and the United States...I applied, but [have not heard back]...I have interviewed twice for an instructor position in California...but the salary was too low for my family... we may have to live under the poverty line...the financial concern is strong...

In conclusion, by using the lens of the Social Cognitive Career Theory (Dos Santos, 2019d, 2020a; Lent et al., 1994; Lent \& Brown, 1996), the researcher confirmed through the results of this study that the participants' career decisions were highly influenced by their personal considerations and financial considerations (Dos Santos, 2021a). First, due to family engagement and commitments, the participants had to stay in Korea even if they didn't want to, primarily because of their marriage to a Korean spouse. That finding identified a new direction for career motivation because many studies have indicated that foreign teachers tend to leave their teaching positions within the first few years of a contract (Ingersoll, 2001). Second, financial considerations related to their annual salary and the relationship between their often-limited qualifications and stiff competition from better-qualified applicants also served as a key theme (Weiner \& Jerome, 2016). Because many contemporary job seekers now hold a doctoral degree and have an enhanced academic background, the older, experienced teachers in this study were marked by disadvantageous positions. As a result, and with 
no other choices, the participants were forced to remain in Korea to further their career development.

\section{LIMITATIONS AND FURTHER DEVELOPMENT}

Although this study provided the linkage between the Social Cognitive Career Theory and the motivations of foreign university instructors who have provided teaching services at one of the Korean universities for more than 15 successive years, it has several limitations.

First, some scholars may argue the numbers of participants $(\mathrm{N}=10)$. However, the researcher tried his best to confirm the validity of the study. Therefore, the researcher employed three interview sessions in order to increase the validity of the study. Furthermore, the researcher confirmed the data with the member checking technique.

Second, some scholars may argue that the data from ten participants cannot represent the understanding and situation. However, it is uncommon to recruit a large number of participants with the targeted background (i.e. foreign university instructors with more than 15 successive years of teaching experience at the same university). In order to increase the meaning of the study, due to the application of the Interpretative Phenomenological Analysis, the researcher had collected in-depth and rich data from the participants. Therefore, three interview sessions had been employed. The current indepth data and sharing are intensive and solid (i.e. to represent the holistic picture).

Third, some scholars may argue that the mixed methodology could be beneficial to the readers and related researchers in this area. However, as the current study employed the Interpretative Phenomenological Analysis as the methodology, only qualitative research data and information were collected. Future research studies may employ the mixed methodology in order to expand the population and comments from some similar groups of people.

Fourth, some scholars may argue that the place of origin of the participants should be disclosed. However, the researcher advocated that the experiences and lived stories are the most important point for this study. Therefore, due to privacy and human subject protection, the researcher decided to mask the participants' place of origin and nationality. Please refer to the human subject protection section. Future research studies may disclose the information in order to increase the density of the study.

\section{CONCLUSION}

This study has contributed to research practices devoted to teachers' professional development and career development of foreign teachers in an international location. First, the shortage of teachers and educational staff is significant in all locations, regardless of the populations. This research study and related outcomes served as a blueprint for human resources planners, school leaders, government agencies, policymakers, potential teachers, and researchers to polish and reform their human resources planning, recruitment strategies, and employees' morale management. 
Second, the East Asian region is one of the popular destinations for many international students, teachers, and professionals to develop their career goals and personal achievements. International and foreign professionals may take this study as opportunities for consideration. In fact, working and studying in foreign countries and regions can be difficult and meaningful to many individuals and groups. Before this significant move, individuals should evaluate and measure their own understanding and background. Otherwise, negative outcomes maybe happened.

Third, the East Asian region is one of the popular destinations for many foreign workers and professionals. However, many professionals decided to leave the region within the first few years of their services due to social and cultural differences. Therefore, this study provided a career perspective from foreign workers in South Korea. The in-depth and rich sharing and lived stories may increase the understanding of the background of the South Korean working environment to the potential workforce.

\section{REFERENCES}

Aeschlimann, B., Herzog, W., \& Sander, F. (2019). Irregular teacher turnover and student academic achievement in high schools: A study in the subjects mathematics, German, French and history. Journal of Education and Learning, 8(2), 25. https://doi.org/10.5539/jel.v8n2p25

Aghaei, P., Bavali, M., \& Behjat, F. (2020). An in-depth qualitative study of teachers' role identities: A case of Iranian EFL teachers. International Journal of Instruction, 13(2), 601-620. https://doi.org/10.29333/iji.2020.13241a

Allen, R., Burgess, S., \& Mayo, J. (2018). The teacher labour market, teacher turnover and disadvantaged schools: new evidence for England. Education Economics, 26(1), 4 23. https://doi.org/10.1080/09645292.2017.1366425

Amtu, O., Makulua, K., Matital, J., \& Pattiruhu, C. M. (2020). Improving student learning outcomes through school culture, work motivation and teacher performance. International Journal of Instruction, 13(4), 885-902. https://doi.org/10.29333/iji.2020.13454a

Atteberry, A., Loeb, S., \& Wyckoff, J. (2017). Teacher churning: Reassignment rates and implications for student achievement. Educational Evaluation and Policy Analysis, 39(1), 3-30. https://doi.org/10.3102/0162373716659929

Clandnin, D., \& Connelly, F. (2000). Narrative inquiry: Experience and story in qualitative research. Jossey-Bass.

Creswell, J. (2012). Qualitative inquiry and research design: Choosing among five approaches. Sage.

Cushner, K. (2007). The role of experience in the making of internationally-minded teachers. Teacher Education Quarterly, 34(1), 27-39.

Davis, J., \& Wilson, S. M. (2000). Principals' efforts to empower teachers: Effects on teacher motivation and job satisfaction and stress. The Clearing House: A Journal of 
Educational Strategies, Issues and Ideas, 73(6), 349-353. https://doi.org/10.1080/00098650009599442

Dos santos, L. M. (2020). Becoming university language teachers in South Korea: The application of the interpretative phenomenological analysis and social cognitive career theory. Journal of Education and E-Learning Research, 7(3), 250-257. https://doi.org/10.20448/journal.509.2020.73.250.257

Dos Santos, L. M. (2019a). Bilingual English education: Expectation of parents who enrol their children in bilingual primary schools. International Journal of Instruction, 12(4), 747-766. https://doi.org/10.29333/iji.2019.12448a

Dos Santos, L. M. (2019b). Engineering education as a second career: The experience of female practising engineers. Global Journal of Engineering Education, 21(3), 202207.

Dos Santos, L. M. (2019c). English language learning for engineering students: Application of a visual-only video teaching strategy. Global Journal of Engineering Education, 21(1), 37-44.

Dos Santos, L. M. (2019d). Recruitment and retention of international school teachers in remote archipelagic countries: The Fiji experience. Education Sciences, 9(2), 132. https://doi.org/10.3390/educsci9020132

Dos Santos, L. M. (2020a). Becoming a pre-school and elementary school educator: How do male teachers describe their career decision and career development from the perspective of the social cognitive career approach and human resource management. Journal of Education and E-Learning Research, 7(2), 159-166. https://doi.org/10.20448/journal.509.2020.72.159.166

Dos Santos, L. M. (2020b). Male nursing practitioners and nursing educators: The relationship between childhood experience, social stigma, and social bias. International Journal of Environmental Research and Public Health, 17(14), 4959. https://doi.org/10.3390/ijerph17144959

Dos Santos, L. M. (2021a). Developing bilingualism in nursing students: Learning foreign languages beyond the nursing curriculum. Healthcare, 9(3), 326. https://doi.org/10.3390/healthcare9030326

Dos Santos, L. M. (2021b). Self-efficacy and career decision of pre-service secondary school teachers: A phenomenological analysis. International Journal of Instruction, 14(1), 521-536. https://doi.org/10.29333/iji.2021.14131a

Grissom, J., Viano, S., \& Selin, J. (2016). Understanding employee turnover in the public sector: Insights from research on teacher mobility. Public Administration Review, 76(2), 241-251. https://doi.org/10.1111/puar.12435

Han, S. W., Borgonovi, F., \& Guerriero, S. (2018). What motivates high school students to want to be teachers? The role of salary, working conditions, and societal evaluations 
about occupations in a comparative perspective. American Educational Research Journal, 55(1), 3-39. https://doi.org/10.3102/0002831217729875

Hardman, J. (2001). Improving recruitment and retention of quality overseas teachers. In S. Blandford \& M. Shaw (Eds.), Managing International Schools (pp. 123-135). Routledge Falmer.

Ingersoll, R. M. (2001). Teacher turnover and teacher shortages: An organizational analysis. American Educational Research Journal, 38(3), 499-534. https://doi.org/10.3102/00028312038003499

Jones, M. (2017). Career commitment of nurse faculty. Research and Theory for Nursing Practice, 31(4), 364-378. https://doi.org/10.1891/1541-6577.31.4.364

Kartika, G., \& Purba, D. E. (2018). Job satisfaction and turnover intention: The mediating effect of affective commitment. Psychological Research on Urban Society, 1(2), 100. https://doi.org/10.7454/proust.v1i2.34

Kim, G., \& Kilkey, M. (2018). Marriage migration policy in South Korea: Social investment beyond the nation state. International Migration, 56(1), 23-38. https://doi.org/10.1111/imig.12350

Lam, B., \& Yan, H. (2011). Beginning teachers' job satisfaction: the impact of schoolbased factors. Teacher Development, 15(3), 333-348. https://doi.org/10.1080/13664530.2011.608516

Larkin, M., \& Thompson, A. (2011). Interpretative phenomenological analysis. In A. R. Thompson \& D. Harper (Eds.), Qualitative research methods in mental health and psychotherapy: A guide for students and practitioners (pp. 99-116). John Wiley \& Sons, Ltd. https://doi.org/10.1002/9781119973249

Lee, J., Jon, J., \& Byun, K. (2017). Neo-racism and neo-nationalism within East Asia. Journal of Studies in International Education, 21(2), 136-155. https://doi.org/10.1177/1028315316669903

Lent, R. W., \& Brown, S. D. (1996). Social cognitive approach to career development: An overview. The Career Development Quarterly, 44(4), 310-321. https://doi.org/10.1002/j.2161-0045.1996.tb00448.x

Lent, R. W., Brown, S. D., \& Hackett, G. (1994). Toward a unifying social cognitive theory of career and academic interest, choice, and performance. Journal of Vocational Behavior, 45(1), 79-122. https://doi.org/10.1006/jvbe.1994.1027

Merriam, S. B. (2009). Qualitative research: A guide to design and implementation. Jossey Bass.

Mowday, R., Porter, L., \& Steers, R. (1981). Employee-organization Linkages: The psychology of employee commitment, bbsenteeism, and turnover. Academic Press.

Odland, G., \& Ruzicka, M. (2009). An investigation into teacher turnover in schools. Journal of Research in International Education, 8(1), 5-29. 
Seidman, I. (2013). Interviewing as qualitative research: A guide for researchers in education and the social sciences (4th ed.). Teachers College Press.

Smith, J., Flower, P., \& Larkin, M. (2009). Interpretative phenomenological analysis: Theory, method, and research. Sage.

Sutcher, L., Darling-Hammond, L., \& Carver-Thomas, D. (2019). Understanding teacher shortages: An analysis of teacher supply and demand in the United States. Education Policy Analysis Archives, 27(1), 35. https://doi.org/10.14507/epaa.27.3696

Tang, K. H., \& Dos Santos, L. M. (2017). A brief discussion and application of interpretative phenomenological analysis in the field of health science and public health. International Journal of Learning and Development, 7(3), 123-132. https://doi.org/10.5296/ijld.v7i3.11494

Todd, R., \& Darasawang, P. (2020). English language teacher education in Thailand: A mix of global and local. In A. B. M. Tsui (Ed.), English Language Teaching and Teacher Education in East Asia: Global Challenges and Global Reponses (pp. 195216). Cambridge University Press.

Tsui, A. B. M. (2020). Glocalization and grobalization: Critical issues in English language teaching and teacher education in East Asia. In A. B. Tsui (Ed.), English Language Teaching and Teacher Education in East Asia (pp. 1-36). Cambridge University Press. https://doi.org/10.1017/9781108856218.002

Wahyudiati, D., Rohaeti, E., Irwanto, I., Wiyarsi, A., \& Sumardi, L. (2020). Attitudes toward chemistry, self-Efficacy, and learning experiences of pre-service chemistry teachers: Grade level and gender differences. International Journal of Instruction, 13(1), 235-254. https://doi.org/10.29333/iji.2020.13116a

Watlington, E., Shockley, R., Guglielmino, P., \& Felsher, R. (2010). The high cost of leaving: An analysis of the cost of teacher turnover. Journal of Education Finance, 36(1), 22-37. https://doi.org/10.1353/jef.0.0028

Weiner, L. (2012). The future of our schools: teachers unions and social justice. Haymarket Books.

Weiner, L., \& Jerome, D. (2016). Urban teaching: The essentials (3rd ed.). Teachers College Press. 